\title{
The Effect of Academic Involvement and School Climate as Perceived by Gifted Students in Terms of Talent, Creativity, and Motivation in Science ${ }^{i}$
}

\author{
Çiğdem Akkanat ${ }^{1, *}$, Murat Gökdere ${ }^{2}$ \\ ${ }^{1}$ Ministry of National Education, Amasya Directorate, 05200, Amasya, Turkey \\ ${ }^{2}$ Faculty of Education, Amasya University, Amasya, Turkey
}

Copyright $\bigcirc 2018$ by authors, all rights reserved. Authors agree that this article remains permanently open access under the terms of the Creative Commons Attribution License 4.0 International License

\begin{abstract}
When drawing up the educational conditions offered to gifted students, it is important to be aware of their characteristics and to reveal the variables affecting their learning processes. Even though there are institutions in many countries that provide services for gifted individuals, there are relatively few studies on how students assess the climate in these institutions and how the institutional climate influences the learning process. Therefore, we investigated the influence of motivation, talent, and creativity levels of students attending Science and Arts Centers, an educational institution in Turkey for gifted students, regarding science classes, the role of academic involvement and parent and teacher support, and the school climate as perceived by students. In this context, 997 gifted students selected through stratified sampling provided the data for the study. When parental and teacher support and school climate perceived by gifted students are considered together, this significantly predicts the students' motivation toward science, their levels of scientific creativity, and science talents. The findings of this study were examined considering the current literature, and the limitations of the study and suggestions for future research are presented.
\end{abstract}

Keywords Gifted, Parental Involvement, School Climate, Talent, Creativity, Motivation

\section{Introduction}

Scientific developments are the products of hard efforts made by groups of scientists in various fields of science. As science progresses rapidly in the ever-changing world, the methods used by scientists in keeping up with this change, the motivation of the school-age children who will become scientists in the future and their potential for success in science attract the attention of educational researchers. Outstanding success in science is a result of a complex process influenced by psychological, social, and contextual factors [1]. We see that the individuals who have the potential to display outstanding achievement in the field of science are called "the gifted in science" in the literature $[2,3]$.

Heller [4] defined being gifted in science as a special talent for the potential of scientific thinking and outstanding skills in natural sciences. According to Taber [3], the traits that characterize the gifted in science are curiosity, higher cognitive skills, and meta-cognitive maturity. Yager [5], however, presented the indicators of being gifted in science as follows:

- Strong interest in objects and the environment

- High interest in researching scientific phenomena

- The tendency to make observations and ask questions

- Ability to establish relationships between the phenomena observed and scientific concepts

- Outstanding talent in presenting creative and up-to-date statements

- High interest in collecting, separating, and classifying objects.

It is widely accepted by many researchers that talent is a developmental feature [6]. In addition, many studies have shown that cognitive skills, emotional skills, personality traits, and educational opportunities are influential in the development of science competence $[4,7,8,9]$. When opportunities and supports are not offered, skills may develop more slowly or the student may suffer from such a lack [10]. Outstanding talent is not a guarantee of success, and there are many factors involved in this process [11].

School and family are important variables in the development of talent. Family and school experiences are influential in the development of children's motivation toward their classes and sustaining it throughout the school life. Epstein [12] found that the level of education 
increased when strong links were established between home and school. In science, outstanding performance is seen to be positively affected by parental academic involvement and supportive parenting approaches [13-16]. Albert [17] determined that those with outstanding achievements in science come from families with well-adjusted, easy-going, and compromising members. Cho and Campbell [18] showed that the gifted in science are more often and more strongly influenced by family processes at an early age and that their families continue to support and assist them also during high school.

It is important to develop the field-specific skills and motivations of the gifted in an educational setting because one of the main reasons for the failure of gifted students is the lack of motivation [19]. Many teachers assume that gifted students are more motivated than moderately successful students [20], but this is not always the case [7]. With gifted learners, it is essential to create a learning environment in which risk taking is tolerated, opinions are valued and supported, and freedom, creativity, and autonomy are adopted as a principle [21]. Academic achievement and all developments in the learning process depend on the harmony between the individual's abilities and the learning environment [22]. They need content with a suitable difficulty level, considering their level of talent, to avoid such problems [23].

There is a variety of educational institutions dedicated to gifted learners. These institutions aim to offer educational opportunities specific to the individual differences of students through different strategies such as enrichment and accelerating. In the Turkish context, these institutions are named Science and Arts Centers, and they admit students based on various diagnostic criteria (e.g., IQ coefficient, teacher evaluations, and skill points). In these institutions, gifted learners are grouped according to their skill areas and study from grade 2 until grade 12. Just like every other institution, these institutions have a number of distinctive characteristics, an "institutional identity" in a sense, that distinguish them from other institutions [24]. This institutional identity is named the school climate in educational literature. The school climate is generally defined based on people's experiences with school life, as a general structure that involved the norms, goals, values, interpersonal relations, teaching-learning process, and organizational structures [25]. Inter-individual relations, the nature of the learning-teaching process that takes place in this process, and the physical, social, and emotional security of the students take part in the school climate [26]. Positive school climate leads to increased student involvement and loyalty to the school, increased motivation, increased success, and a decrease in undesirable behaviors [27-29]. In addition, the social environment in the classroom and the positive relationships within the classroom are influential in the development of positive attitudes toward schools and classes [30]. Science teachers can also help students grow up as talented young scientists by appropriately identifying gifted students and providing new points of interest and positive learning experiences [31].

An investigation of some environmental factors that affect the talent, creativity, and motivation in science class will be a guide for the steps to be taken. The education of students with high potentials in science is important both for the individual development of the child and for the economic development of the countries through advancements in science and technology.

This study aims to examine the link between the perceptions of parental and teacher academic involvement and school climate and the levels of talent and motivation. The research questions under focus were as follows:

1. Do perceived school climate and perceived parental and teacher academic involvement significantly predict motivation toward science?

2. Do perceived school climate and perceived parental and teacher involvement significantly predict science talent?

3. Do perceived school climate and perceived parental and teacher involvement significantly predict scientific creativity?

\section{Materials and Methods}

\subsection{Research Design}

This study aims to reveal the relationship between factors such as the academic involvement of parents and teacher and school climate, as perceived by gifted students, and their motivation for learning science, creativity, and talent in science. Relational screening model was used since the study required an investigation of relationships between the variables without creating an effect in order to change the current situation.

\subsection{Sample}

The research sample consisted of 997 students who were previously identified as gifted in the mental field and selected through stratified sampling method. Of all the forms collected, 52 forms were excluded from the sample because they were mostly unfilled. For the analysis of the data, univariate normality and multivariable normality conditions were examined and extreme values were excluded from the data set. Data from 698 students were included in the analysis.

\subsection{Data Collection Tools}

Science Ability Test, Scientific Creativity Test, School Climate Scale, Perceived Parental and Teacher Academic Involvement Scale, and Science Learning Motivation Scale were used to collect data. 


\subsubsection{Science Ability Test}

This is a test developed by Akkanat and Gökdere [32] to reveal the achievement levels of students in employing scientific logic and scientific process skills that may be indicative of the science talent in students. This test consists of 21 multiple-choice items. The internal consistency coefficient of the test (KR 20) was found to be .85 . CFA analyses confirmed the model and that the scale has a single factor with good fit indices $\left(\chi^{2}=721.29\right.$ $(d f=188, p<.001),\left(x^{2} / d f\right)=3.83$, GFI $=.91$, RMSEA $=.06$, $\mathrm{CFI}=.89$ and $\mathrm{AGFI}=.89)$. The internal consistency coefficient (KR20) for this administration was found to be .737 .

\subsubsection{Scientific Creativity Test}

Scientific Creativity Scale, developed by $\mathrm{Hu}$ and Adey [33] and adapted to the Turkish context by Deniş-Çeliker and Balım [34], was used to measure the scientific creativity of students. The CFA analysis of the one-factor scale indicates an acceptable fit. $\left(\chi^{2}=62.08(d f=14\right.$, $p<.001),\left(x^{2} / d f\right)=4.42$, GFI $=.98$, RMSEA $=.07$, CFI $=.96$ and $\mathrm{AGFI}=.95$. For this study, the Cronbach alpha internal consistency coefficient of the scale was found to be .66 .

\subsubsection{Students' Motivation toward Science Learning Scale}

"Students' Motivation toward Science Learning Scale" developed by Tuan, Chin and Shieh [35], was used to determine the motivation of students to learn science. The validity and reliability analyzes of the scale in Turkey were made by Yılmaz and Çavaş [36]. They found the Cronbach alpha reliability coefficient as .87 in the reliability studies of the scale. In this study, the CFA and EFA analyzes were repeated for the sample of gifted learners. Factor load values ranged from .44 to .76 for the scale consisting of 33 items and 6 sub-dimensions. The total variance explained is 53.3 . It can be said that the fit indices obtained confirm the model $\left(\chi^{2}=1439.9(d f=457\right.$, $p<.001),\left(x^{2} / d f\right)=3.14, \mathrm{GFI}=.89$, RMSEA $=.05, \mathrm{CFI}=.97$ and AGFI $=.87$ ). The Cronbach alpha internal consistency coefficient of the scale was found to be .89 .

\subsubsection{School Climate Scale}

School Climate Scale, developed by Çalık and Kurt [37] to reveal the perceptions of the students about the school climate, was adapted for use in Science and Arts Center, which is the institution that offers education to gifted students. The adapted form of the scale consists of 21 items and 4 sub-dimensions. Factor load values range from .46 to .78 . The total variance explained is 55.05 . The fit indices obtained from CFA are excellent $\left(\chi^{2}=621.92\right.$ $(d f=185, p<.001),\left(x^{2} / d f\right)=3.36$, GFI $=.92$, RMSEA $=.05$, $\mathrm{CFI}=.97$ and $\mathrm{AGFI}=.90)$. The Cronbach alpha internal consistency coefficient was .88 for the scale.

\subsubsection{Perceived Parental and Teacher Academic Involvement Scale}

Perceived Parental and Teacher Academic Involvement Scale, developed by Régner, Loose and Dumas [38] and adapted to the Turkish context by Dündar [39], was used to determine the level of parental involvement as perceived by students. CFA and EFA analyses were conducted because the scale was used for gifted students for the first time. Factor load values vary between .56 and .86 in the model consisting of 13 items and 4 factors. The total variance explained is 73.8. The fit indices obtained as a result of CFA are at the desired level $\left(\chi^{2}\right.$ $=298.16 \quad(d f=59, \quad p<.001), \quad\left(x^{2} / d f\right) \quad=5, \quad \mathrm{GFI}=.94$, RMSEA $=.07, \mathrm{CFI}=.98$, and AGFI $=.90$ ). The Cronbach alpha internal consistency coefficient was found to be .90 for the scale.

\subsection{Data Collection Process}

First, the approval to administer the tests was granted by the Ministry of National Education. Next, after contacting the directors at Science and Arts Centers in Turkey, which offer education to the gifted students in Turkey, the data collection tools were administered to students by the researcher.

\subsection{Data Analysis}

Descriptive analysis and regression analysis were used in the analysis of the data. SPSS Statistics 17 software was used in the analysis of the data.

\section{Findings}

Firstly, descriptive statistics of data collection tools were examined. Descriptive statistics regarding the scales in this study are presented in Table 1.

Motivation levels of the students in this study were high. They had a positive school climate perception and their perceived parental and teacher involvement levels were very high. The link between students' motivation to learn science and school climate perceptions and parental and teacher academic involvement was examined by multiple regression analysis. Results related to the analysis can be seen in Table 2 .

Table 1. Descriptive statistics

\begin{tabular}{|c|c|c|c|c|}
\hline The scales $(\mathrm{N}=698)$ & Min. & Max. & $\boldsymbol{M}$ & $\boldsymbol{S D}$ \\
\hline Motivation & 2.55 & 5.00 & 4.07 & 0.51 \\
\hline Scientific creativity & 2.00 & 83.00 & 38.45 & 17.06 \\
\hline Science ability & 4.00 & 20.00 & 13.39 & 3.73 \\
\hline School climate & 2.24 & 5.00 & 4.04 & 0.64 \\
\hline $\begin{array}{c}\text { Perceived academic } \\
\text { involvement }\end{array}$ & 1.50 & 5.00 & 4.11 & 0.79 \\
\hline
\end{tabular}


Table 2. Multiple Regression Analysis for Predicting Motivation

\begin{tabular}{|c|c|c|c|c|c|c|}
\hline Model & Variable & $\boldsymbol{B}$ & Standard error & $\boldsymbol{\beta}$ & $\boldsymbol{t}$ & $\boldsymbol{p}$ \\
\hline \multirow{3}{*}{1} & Fixed & 2.34 & 0.12 & & 20.26 & .000 \\
\cline { 2 - 7 } & Academic involvement & 0.17 & 0.02 & 0.26 & 7.12 & .000 \\
\cline { 2 - 7 } & School climate & 0.26 & 0.03 & 0.33 & 8.90 & .000 \\
\hline \multicolumn{3}{|c|}{$R=0.497 \quad R^{2}=0.247$} \\
\hline
\end{tabular}

Perceived academic support and school climate had a significant relationship with motivation $\operatorname{scores}\left(R=0.497, R^{2}=\right.$ $0.247, p<0.01)$. These variables together account for $25 \%$ of the total variance in motivation. The model was successful in predicting motivation $\left(F_{(2.695)}=114.062, p<0.01\right)$. According to the standardized regression coefficient $(\beta)$, among the predictive variables, the variable which had the greatest effect on motivation was the school climate.

The relation between students' scientific creativity and school climate perceptions and parental and teacher academic involvement was examined by multiple regression analysis. Results related to the analysis can be seen in Table 3 .

Table 3. Multiple Regression Analysis for Predicting Creativity

\begin{tabular}{|c|c|c|c|c|c|c|}
\hline \multirow{2}{*}{ Model } & Variable & $\boldsymbol{B}$ & Standard error & $\boldsymbol{\beta}$ & $\boldsymbol{t}$ & $\boldsymbol{p}$ \\
\hline \multirow{3}{*}{1} & Fixed & 17.46 & 4.40 & & 3.98 & .000 \\
\cline { 2 - 7 } & Academic involvement & -0.74 & 0.90 & -0.034 & -0.83 & .407 \\
\cline { 2 - 7 } & School climate & 5.94 & 1.09 & .224 & 5.45 & .000 \\
\hline \multicolumn{3}{|c|}{$R=0.211 \quad R^{2}=0.45$} \\
\hline
\end{tabular}

Perceived academic support and school climate had a significant relationship with scientific creativity scores $(R=$ $\left.0.211, R^{2}=0.45, p<0.01\right)$. These variables account for $45 \%$ of the total variance in scientific creativity. The model was successful in predicting creativity $\left(F_{(2,695)}=16,228, p<0.01\right)$. The standardized regression coefficient $(\beta)$ showed that school climate has the most significant effect among the predictive variables. The results of a t-test on the significance of the regression coefficients showed that the effect of perceived academic involvement is not significant $(t=-0.829$, $p>0.01)$.

The link between students' scientific aptitude and school climate perceptions and parental and teacher academic involvement was examined by multiple regression analysis. Results related to the analysis can be seen in Table 4 .

Table 4. Multiple Regression Analysis for Predicting Science Ability

\begin{tabular}{|c|c|c|c|c|c|c|}
\hline Model & Variable & $\boldsymbol{B}$ & Standard error & $\beta$ & $t$ & $p$ \\
\hline \multirow{3}{*}{1} & Fixed & 9.16 & 0.96 & & 9.53 & .000 \\
\hline & Academic involvement & -0.23 & 0.19 & -0.05 & -1.17 & .243 \\
\hline & School climate & 1.28 & 0.24 & 0.22 & 5.34 & .000 \\
\hline \multicolumn{7}{|c|}{$R=0.204 \quad R^{2}=0.042$} \\
\hline
\end{tabular}

Perceived academic support and school climate had a significant relationship with scientific aptitude scores $(R=$ $\left.0.204, R^{2}=0.042, p<0.01\right)$. These variables account for $4 \%$ of the total variance in scientific aptitude. The model was successful in predicting motivation $\left(F_{(2,695)}=15,084, p\right.$ $<0.01)$. The standardized regression coefficient $(\beta)$ showed that school climate has the most significant effect among the predictive variables. The results of a t-test on the significance of the regression coefficients showed that the effect of perceived academic participation is not significant $(t=-1,168, p>0.01)$.

\section{Discussion and Conclusions}

Investigating motivation, creativity, and aptitude in learning science in the context of parental and teacher academic involvement and school climate, this study found a number of important results that will contribute to practice in this field. It was observed that the students who participated in this study had a high motivation to learn science, a positive perception of school climate, and a high level of perceived parental and teacher academic involvement. 
The literature on the gifted learners indicates that they have a high motivation to learn science [40], they perceive the climate at schools that serve exclusively to them as being positive [41], and they believe they receive sufficient support from their parents and teachers [42].

According to Hennessey [43], the quality of being gifted can develop when appropriate conditions exist between the individual and the environment; intrinsic motivation and creativity thrive in situations where there are no external restrictions, so if student motivation, creativity, and special skills are to be developed, the school climate should be approached with great care (p.62). Academic involvement and school climate perceived by gifted students together have a significant relationship with motivation scores. This indicates that parents, teachers, and the school climate together influence student motivation. There are other studies that support the results of this study. Lüftenegger et al. [44] determined that successful gifted students had a higher motivation than non-successful students and that they perceived the class as a construct that focuses on learning and contains activities that are more autonomous. Al-Dhamit and Kreishan [45] found a significant relationship between parental support and internal and external motivation levels. Sakiz [46] found that perceived teacher emotional support can help students achieve positive attitudes and motivation in science classes. Anderson, Hamilton, and Hattie [47] examined the relationship between various motivational variables and school climate and found that school climate was significantly associated with involvement, interest, and task completion variables. Velayutham and Aldridge [48] touched upon the link between learning science and the psychosocial learning environment and found that it is important for student self-regulation and motivation.

There are also studies with different results regarding the effect of parents on motivation. For example, Garn, Matthews, and Jolly [49] noted that parents play an important role in shaping the academic motivation of gifted students and examined their home settings, but determined that their parents are inconsistent in providing academic motivation despite having good intentions.

The peer environment also stands out as an important factor. In fact, Nelson and DeBaker [50] investigated the relationship between achievement motivation and peer influence among science students and found that students who think that they are perceived as valuable and respectable by their peers have more adaptive achievement motivation.

Csikszentmihalyi [51] approached creativity as a consequence of the interaction with the individual's environment. Concerning education, the variables of parents, teachers, and school stand out as the environmental factors. According to Cole, Sugioka and Yamagata-Lynch [52], if education aims to prepare children for a productive life in society, the education system needs to accept responsibility for supporting and developing creativity. In our study, it was found that academic involvement and school climate, as perceived by gifted students, were significantly correlated with scientific creativity scores. There are different studies that support these results [53, 54]. Isaksen and Akkermans [55] determined that innovative productivity increases in organizational climates that support creativity. $\mathrm{Yi}, \mathrm{Hu}$, Plucker, and McWilliams [56] found a significant relationship between creative thinking and school climate. In pedagogical learning environments that support creativity, there seems to be high expectations among students and teachers, and there are relationships that involve flexibility and mutual respect [57]. This envisages the development of creativity within positive teacher and student associations. Moreover, Liu et al. [58] found that parental academic involvement is a mediator between motivation and creative thinking among high school students and determined that together with environmental factors, individual characteristics contribute to the creative thinking of the individual in an interactive manner. Considering all of these, it can be said that environmental factors are important for the development of creativity among the gifted.

Perceived academic support and school climate were found to significantly predict scientific aptitude among gifted learners. However, this predictive power is lower than other variables. This may be due to the effects of several cognitive factors on skill level. It can be seen that this result is well supported in the literature. Fan, Williams, and Corkin [59] stated that the school environment can influence students' learning processes and school experiences through their own perceptions. Cohen, McCabe, Michelli, and Pickeral [26] indicated that school climate has supportive or complicating effects on students' learning skills. In addition to supporting the idea that positive school climate enhances the learning abilities of students, previous studies associate consistently positive school climate with positive child development, student learning and achievement [25].

Further, studies also suggest that social support is related to the level of competence; these studies support this result. For example, Rice, Barth, Guadagno, Smith, and McCallum [60] found that students with social support from parents, teachers, and peers in mathematics and science classes had higher levels of perceived competence. Gerber, Cavallo, and Marek [61] found that school and community activities in which students are actively involved have positive effects on scientific reasoning ability. Beghetto [62] pointed out that the assessments regarding science competence among secondary and high school students are related to the perceived level of support from teachers.

In conclusion, it can be said that besides the involvement of parents and teachers, the school climate, as perceived by children, also contributed significantly to the motivation, talent, and creativity levels in science classes in our study. 
Similar to other studies, this study has some limitations. The involvement of parents and teachers and the school climate could only be assessed based on the dimensions in the questionnaires.

It was assumed that all students at the Science and Art Centers were recognized in a valid and reliable way, and all of them had got a score above the IQ coefficient determined by the Ministry of National Education. It is therefore appropriate that some generalizations made in this respect should be considered in the light of the context of the study. In future studies, the effects of environmental, socioeconomic, and cognitive variables on the development of science ability can be examined. Detailed examination of family, teacher, and other school-related factors will pave the way for improvements in the quality of science education offered to gifted students.

\section{REFERENCES}

[1] Araújo, L. S., Cruz, J. F., \& Almeida, L. S. (2016). Achieving scientific excellence: An exploratory study of the role of emotional and motivational factors. High Ability Studies, 1-19.

[2] Innamorato, G. (1998). Creativity in the development of giftedness: Educational implications. Roeper Review, 21, 54-59.

[3] Taber, K. S. (2007). Science education for gifted learners? K. S. Taber in, Science education for gifted learners (s. 1-14). London: Routledge.

[4] Heller, K. A. (1993). Scientific ability. G. R. Bock, \& K. Ackrill (Dü.), Ciba Foundation Symposium 178-The origins and development of high ability in (s. 139-159). Chichester: Wiley.

[5] Yager, R. E. (1989). Teaching science to gifted science students. R. M. Milgram in Teaching gifted and talented learners in regular classrooms (s. 223-248). Springfield, IL: Charles C. Thomas.

[6] Subotnik, R. F., Olszewski-Kubilius, P., \& Worrell, F. C. (2011). Rethinking giftedness and gifted education: A proposed direction forward based on psychological science. Psychological science in the public interest, 12(1), 3-54.

[7] Andersen, L., \& Cross, T. L. (2014). Are students with high ability in math more motivated in math and science than other students? Roeper Review, 36(4), 221-234.

[8] Cho, S., \& Lin, C.-Y. (2011). Influence of Family Processes, Motivation, and Beliefs About Intelligence on Creative Problem Solving of Scientifically Talented Individuals. Roeper Review, 33, 46-58.

[9] Lubinski, D., \& Benbow, C. P. (1992). Gender differences in abilities and preferences among the gifted: Implications for the math-science pipeline. Current Directions in Psychological Science, 1(2), 61-66.

[10] Subotnik, R. F., \& Jarvin, L. (2005). Beyond expertise: Conceptions of giftedness as great performance. R. J.
Sternberg, \& J. Davidson in, Conceptions of giftedness (2nd Edition b., s. 343-357). New York: Cambridge University Press.

[11] Olszewski-Kubilius, P. (2010). Special Schools and Other Options for Gifted STEM Students. Roeper Review, 32, 61-79.

[12] Epstein, J. L. (1995). School, family, community partnerships: Caring for the children we share. Phi Delta Kappan, 76, 701-712.

[13] Rodrigez, A. J., Collins-Parks, T., \& Garza, J. (2013). Interpreting Research on Parent Involvement and Connecting it to the Science Classroom. Theory into Practice, 52, 51-58.

[14] Şad, S. N. (2012). Investigation of Parental Involvement Tasks as Predictors of Primary Students' Turkish, Math and Science \& Technology Achievement. Eurasian Journal of Educational Research, 49, 173-196.

[15] Bhanot, R. T., \& Jovanovic, J. (2009). The Links Between Parent Behaviors and Boys' and Girls' Science Achievement Beliefs. Applied Developmental Science, 13(1), 42-59.

[16] Ho, E. S. (2010). Family influences on science learning among Hong Kong adolescents: What we learned from PISA. International Journal of Science and Mathematics Education, 8(3), 409-428.

[17] Albert, R. S. (1991). People, processes and developmental paths to eminence: A developmental interactional model. R. M. Milgram in, Counseling gifted and talented children (s. 75-99). NJ: Ablex.

[18] Cho, S., \& Campbell, J. R. (2010). Differential influences of family processes for scientifically talented individuals' academic achievement along developmental stages. Roeper Review, 33(1), 33-45.

[19] Matthews, M. S., \& McBee, M. T. (2007). School factors and the underachievement of gifted students in a talent search summer program. Gifted Child Quarterly, 51(2), $167-181$.

[20] McCoach, D. B., \& Siegle, D. (2003). Factors that differentiate underachieving gifted students from high-achieving gifted students. Gifted Child Quarterly, 47(2), 144-154.

[21] Watters, J. J., \& Diezmann, C. M. (2003). The gifted student in science: Fulfilling potential. Australian Science Teachers Journal, 49(3), 46-53.

[22] Vogl, K., \& Preckel, F. (2014). Full-Time Ability Grouping of Gifted Students: Impacts on Social Self-Concept and School-Related Attitudes. Gifted Child Quarterly, 58(1), 51-68.

[23] Winebrenner, S. (2000). Gifted students need an education, too. Educational Leadership, 58(1), 52-56.

[24] Hayes, A. E. (1973). A Reappraisal of the Halpin-Croft Model of the Organizational Climate of Schools.

[25] Thapa, A., Cohen, J., Guffey, S., \& Higgins-D’Alessandro, A. (2013). A review of school climate research. Review of educational research, 83(3), 357-385.

[26] Cohen, J., McCabe, L., Michelli, N. M., \& Pickeral, T. (2009). School climate: Research, policy, practice, and 
teacher education. Teachers college record, 111(1), 180-213.

[27] İhtiyaroğlu, N., \& Demirbolat, A. O. (2016). Analysis of Relationships between School Climate, Teacher Effectiveness and Students' School Commitment. International Online Journal of Educational Sciences, 8(4), 255-270.

[28] Jayalekshmi, N. B., \& Raja, B. W. (2011). Behavioural Development of Early Adolescents by Dint of Positive School Climate. i-Manager's Journal on Educational Psychology, 5(2), 1-9.

[29] Warner, L., \& Heindel, P. (2017, March). Student Success Built on a Positive School Climate. The Education Digest, 82(7), 10-15.

[30] Ryan, A. M., \& Patrick, H. (2001). The Classroom social environment and changes in adolescents' motivation and engagement during middle school. American Educational Research Jorunal, 38(2), 437-460.

[31] Singh, A. (2008). Professional development and perspectives of science teachers: An extracurricular science program for gifted middle school students (Unpublished Doctorate Thesis). Iowa: The University of Iowa.

[32] Akkanat, C.. \& Gökdere, M. (2017). Students' ability in science: Results from a test development study. Cypriot Journal of Educational Science, 12(1), 14-22.

[33] Hu, W., \& Adey, P. (2002). A scientific creativity test for secondary school students. International Journal of Science Education, 24(4), 389-403.

[34] Deniş Çeliker, H., \& Balım, A. (2012). Bilimsel yaratıcılık ölçeğinin Türkçeye uyarlama süreci ve değerlendirme ölçütleri. Uşak Üniversitesi Sosyal Bilimler Dergisi, 5(2), $1-21$.

[35] Tuan, H. L., Chin, C. C., \& Shieh, S. H. (2005). The development of a questionnaire to measure students' motivation towards science learning. International Journal of Science Education, 27(6), 639-654.

[36] Yılmaz, H., \& Çavaş Huyugüzel, P. (2007). Fen öğrenimine yönelik motivasyon ölçeğinin geçerlik ve güvenirlik çalışması. İlköğretim Online, 6(3), 430-440.

[37] Çalık, T., \& Kurt, T. (2010). Okul iklimi ölçeğinin geliştirilmesi. Eğitim ve Bilim, 35(157), 167-180.

[38] Régner, I., Loose, F., \& Dumas, F. (2009). Students' perceptions of parental and teacher academic involvement: Consequences on achievement goals. European Journal of Psychology of Education, 24(2), 263.

[39] Dündar, Ş. (2014). Algılanan anne-baba ve öğretmen akademik katılım ölçeğinin Türkçeye uyarlanması. Eğitim Bilimleri Araştırmaları Dergisi, 4(1), 369-382.

[40] Gottfried, A. E., \& Gottfried, A. W. (1996). A longitudinal study of academic intrinsic motivation in intellectually gifted children: Childhood through early adolescence. Gifted Child Quarterly, 40(4), 179-183.

[41] Cross, T. L., Stewart, R. A., \& Coleman, L. J. (2003). Phenomenology and its implications for gifted studies research: Investigating the lebenswelt of academically gifted students attending an elementary magnet school. Journal for the Education of the Gifted, 26(3), 201-220.
[42] Shavinina, L. (2013). The role of parents and teachers in the development of scientific talent: Lessons from early childhood and adolescent education of Nobel Laureates. Gifted and Talented International, 28(1-2), 11-24.

[43] Hennessey, B. A. (2004). Developing Creativity in Gifted Children: The Central Importance of Motivation and Classroom Climate. Storrs, Connecticut: The National Research Center on the Gifted and Talented (NRC/GT), University of Connecticut.

[44] Lüftenegger, M., Kollmayer, M., Bergsmann, E., Jöstl, G., Spiel, C., \& Schober, B. (2015). Mathematically gifted students and high achievement: The role of motivation and classroom structure. High Ability Studies, 26(2), 227-243.

[45] Al - Dhamit, Y., \& Kreishan, L. (2016). Gifted students' intrinsic and extrinsic motivations and parental influence on their motivation: from the self - determination theory perspective. Journal of Research in Special Educational Needs, 16(1), 13-23.

[46] Sakiz, G. (2017) Perceived teacher affective support in relation to emotional and motivational variables in elementary school science classrooms in Turkey. Research in Science \& Technological Education, 35(1), 108-129.

[47] Anderson, A., Hamilton, R. D., \& Hattie, J. (2004). Classroom climate and motivated behaviour in secondary schools. Learning Environments Research, 7, 211-225.

[48] Velayutham, S., \& Aldridge, J. M. (2013). Influence of Psychosocial Classroom Environment on Students' Motivation and Self-Regulation in Science Learning: A Structural Equation Modeling Approach. Research in Science Education, 43, 507-527.

[49] Garn, A. C., Matthews, M. S., \& Jolly, J. L. (2010). Parental influences on the academic motivation of gifted students: A self-determination theory perspective. Gifted Child Quarterly, 54(4), 263-272.

[50] Nelson, R. M. \& DeBacker, T. K. (2008). Achievement Motivation in Adolescents: The Role of Peer Climate and Best Friends. The Journal of Experimental Education, 76(2), 170-189.

[51] Csikszentmihalyi, M., 1999. Implications of a systems perspective for the study of creativity. Handbook of Creativity, Ed: R. J. Sternberg. Cambridge University Press, Cambridge, MA, 312-35.

[52] Cole, D. G., Sugioka, H. L., \& Yamagata - Lynch, L. C. (1999). Supportive classroom environments for creativity in higher education. The journal of creative behavior, 33(4), 277-293.

[53] Thomas, N. G., \& Berk, L. E. (1981). Effects of School Environments on the Development of Young Children's Creativity. Child Development, 52, 1153-1162.

[54] Deng, L., Wang, L., \& Zhao, Y. (2016). How creativity was affected by environmental factors and Individual characteristics: A cross-cultural comparison perspective. Creativity Research Journal, 28(3), 357-366.

[55] Isaksen, S. G., \& Akkermans, H. J. (2011). Creative climate: A leadership lever for innovation. The Journal of Creative Behavior, 45(3), 161-187. 
[56] Yi, X., Hu, W., Plucker, J. A., \& McWilliams, J. (2013). Is There a Developmental Slump in Creativity in China? The Relationship between Organizational Climate and Creativity Development in Chinese Adolescents. The Journal of Creative Behavior, 47(1), 22-40.

[57] Davies, D., Jindal-Snape, D., Collier, C., Digby, R., Hay, P., \& Howe, A. (2013). Creative learning environments in education-A systematic literature review. Thinking Skills and Creativity, 8, 80-91.

[58] Liu, G., Zhang, S., Zhang, J., Lee, C., Wang, Y., \& Brownell, M. (2013). Autonomous motivation and Chinese adolescents' creative thinking: The moderating role of parental involvement. Creativity research journal, 25(4), 446-456.

[59] Fan, W., Williams, C. M., \& Corkin, D. M. (2011). A multilevel analysis of student perceptions of school climate: The effect of social and academic risk factors. Psychology in the Schools, 48(6), 632-647.

[60] Rice, L., Barth, J. M., Guadagno, R. E., Smith, G. P., \& McCallum, D. M. (2013). The role of social support in students' perceived abilities and attitudes toward math and science. Journal of youth and adolescence, 42(7), 1028-1040.

[61] Gerber, B. L., Cavallo, A. M., \& Marek, E. A. (2001). Relationships among informal learning environments, teaching procedures and scientific reasoning ability. International Journal of Science Education, 23(5), 535-549.

[62] Beghetto, R. A. (2007). Factors associated with middle and secondary students' perceived science competence. Journal of Research in Science Teaching, 44(6), 800-814.

\footnotetext{
'This paper was written from Çiğdem Akkanat's ongoing doctoral dissertation.
} 